\title{
Mesoscale and seasonal variability of heterotrophic nanoflagellate abundance in an estuarine outflow plume
}

\author{
George B. McManus*, Jed A. Fuhrman** \\ Marine Sciences Research Center, SUNY Stony Brook, New York 11794, USA
}

\begin{abstract}
We measured the abundance of heterotrophic nanoflagellates in the estuarine outflow plume of the Chesapeake Bay, USA, during cruises in February, April, June and August. Changes in abundance were measured during both surface mapping and drifter (time series) operations. Flagellate abundance varied as much within each cruise as across all cruises, and there was little evidence of a seasonal pattern. Abundance ranged from ca $10^{3}$ to $10^{4}$ cells $\mathrm{ml}^{-1}$ on all 4 cruises. Choanoflagellates were an important component of the flagellate community in winter ( $22 \%$ of total numbers), but were less important in other seasons $(<10 \%)$. Modal flagellate size was greatest in February $(4.5 \mu \mathrm{m}$ equivalent spherical diameter) and least in August $(2.5 \mu \mathrm{m})$. In general, flagellate abundance was several-fold higher within the plume, was negatively correlated with salinity, and declined over time as the plume mixed with surrounding coastal water. April was an exception, when downwelling-favorable winds and high freshwater discharge produced strong mixing conditions: in contrast to February, June, and August, there was no strong gradient in flagellate abundance between plume and coastal water. In June and August, size-fractionated microcosm experiments indicated that flagellate growth rates of ca $1 \mathrm{~d}^{-1}$ were balanced by microzooplankton grazing. Thus, net population changes were driven by physical processes. Variations in the bacteria to flagellate biomass ratio, and analysis of relationships among bacterial, flagellate, and phytoplankton abundance, suggest that both substrate supply and grazing can be important controls on bacteria in the plume.
\end{abstract}

\section{INTRODUCTION}

Coastal plumes associated with riverine or estuarine outflows are biologically rich mesoscale features bounded by strong horizontal and vertical salinity gradients (Garvine 1986, Boicourt et al. 1987). Abundances and growth rates of phytoplankton, bacterioplankton, and zooplankton are typically higher than in surrounding coastal waters (Malone \& Chervin 1979, Stepien et al. 1981, Albright 1983, Ducklow \& Kirchman 1983, Malone et al. 1983, Kirchman et al. 1989, Malone \& Ducklow in press). Because plumes persist as semiisolated systems for time periods exceeding the gener-

Present addresses

- University of Maryland Center for Environmental and Estuarine Studies, Chesapeake Biological Laboratory, Box 38, Solomons, Maryland 20688, USA

- Department of Biological Sciences, University of Southern California, Los Angeles, California 90089-0371, USA ation times of the microbial plankton (0.5 to $5 \mathrm{~d}$ ), microbial population dynamics can be studied in situ as a plume mixes with coastal water.

The present study reports observations made on the abundance and dynamics of small flagellated protozoa in the Chesapeake Bay, USA, outflow plume. These 'nanoflagellates' are significant grazers of bacterioplankton (Haas \& Webb 1979, Fenchel 1982b, Sherr et al. 1983, McManus \& Fuhrman 1988), and can also ingest photosynthetic picoplankton and larger phytoplankton (Johnson et al. 1982, Landry et al. 1984, Goldman \& Caron 1985, Iturriaga \& Mitchell 1986, Suttle et al. 1986). Because they have short generation times, on the order of hours to a few days (Fenchel 1982a), they are able to respond to short-term changes in abundance of food organisms, and thus play an important role in the close coupling among microbial groups responsible for the cycling of nutrients (Goldman 1984, Goldman et al. 1985). We investigated variability of heterotrophic nanoflagellate abundance within the plume and across 
its boundaries, and compared this variability to temporal changes in abundance within the plume during drogue studies. Relationships between flagellate variability and that of phytoplankton, bacteria, and hydrography were examined to determine the degree of coupling among populations of organisms in the plume and the relative importance of physical factors in regulating nanoflagellate population size.

\section{METHODS}

Cruises were undertaken in the Chesapeake Bay outflow plume in February, June, and August 1985. and in April 1986, as part of the MECCAS program (Microbial Exchanges and Coupling in Coastal Atlantic Systems; Boicourt et al. 1987; Fig. 1). Sampling was conducted in 2 modes: a 'mapping' mode in which the spatial distributions of biological and physical properties were surveyed, and a 'drogue' mode in which the plume was sampled while following surface drifters for periods of 1 to $3 \mathrm{~d}$. Data from 12 map and 11 drogue operations are reported in this paper. Drogue tracks

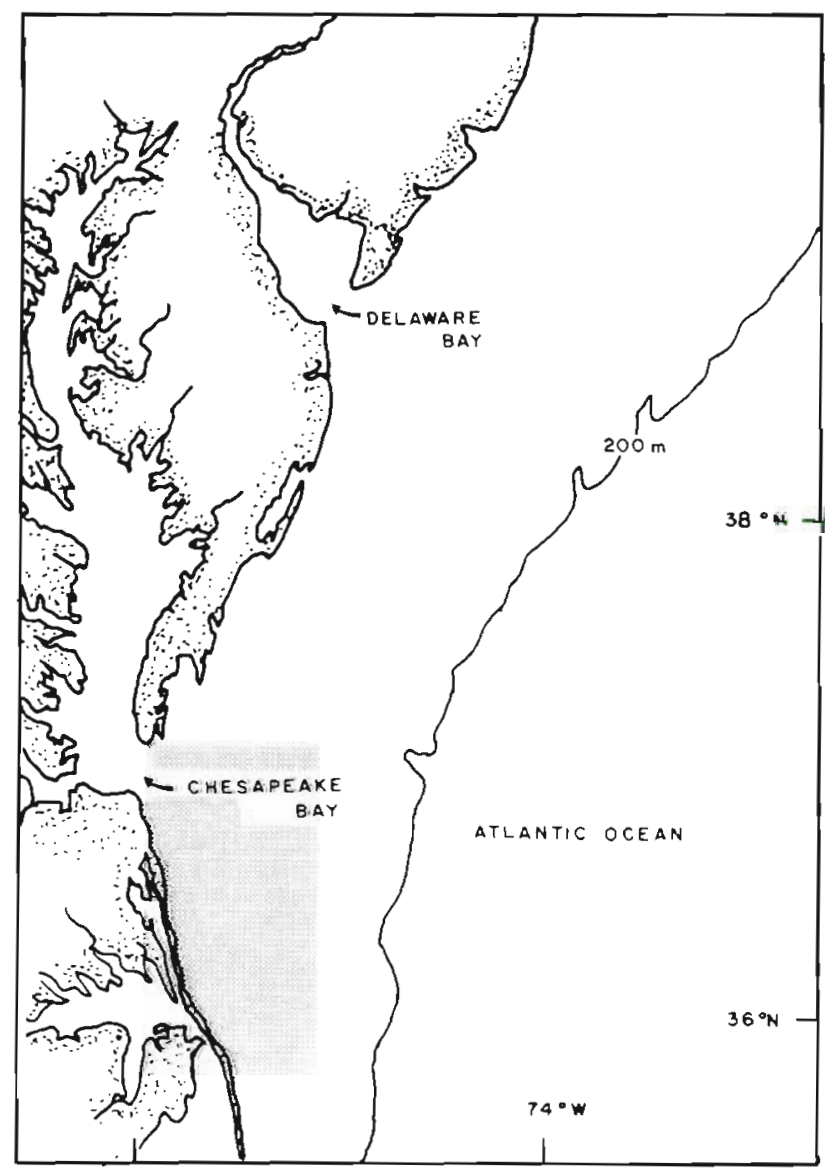

Fig. 1 The mouth of Chesapeake Bay on the northeast coast of the USA. Shaded area indicates study region and maps of bacterial and phytoplankton distributions during the study are given in Malone \& Ducklow (in press).

During mapping, samples were taken from the outflow of a plankton pump used to collect water for vertical profiles of temperature, salinity, and in vivo fluorescence of phytoplankton. Only surface values of flagellate abundance during mapping are reported here. During drogue operations, water was collected in 301 Niskin bottles at 4 to $8 \mathrm{~h}$ intervals. Samples of $20 \mathrm{ml}$ were preserved with $1 \%$ (final concentration) filtered glutaraldehyde and stored at $4{ }^{\circ} \mathrm{C}$ for 12 to $24 \mathrm{~h}$ before slides for enumeration of flagellates were prepared. Subsamples of $10 \mathrm{ml}$ were stained with $1.65 \mu \mathrm{g} \mathrm{ml} \mathrm{m}^{-1}$ proflavine hemisulfate (Haas 1982), filtered onto $0.8 \mu \mathrm{m}$ pore size Nuclepore filters, and mounted in Cargille's Type A immersion oil on glass slides. The slides were stored frozen (at $-20^{\circ} \mathrm{C}$ ) until they could be counted (Bloem et al. 1986).

The slides were examined on an Olympus BH2 epifluorescence microscope equipped with a $50 \mathrm{~W}$ mercury lamp. All cells 2 to $20 \mu \mathrm{m}$ in length that fluoresced only green (proflavine) and not red or red-orange (photosynthetic pigments) were counted as heterotrophs. Although the great majority of these cells possessed flagella, some non-flagellated cells were included. It is presumed that for these organisms flagella were lost in preservation or not adequately stained. At least 50, and more often 100, flagellates were counted per sample. Ciliates in the same size range were rarely encountered at the magnification we used $(1250 \times)$. Flagellates were measured with an eyepiece reticle and volumes were calculated based on assumed spherical or prolate spheroid shape. A value of $0.1 \mathrm{fgC} \mathrm{um}^{3}$ was used to convert biovolume to carbon; this may be conservative for forms that shrink upon preservation (Børsheim \& Bratbak 1987). Bacterial abundance data were based on acridine orange direct counts (Hobbie et al. 1977; data provided by $\mathrm{H}$. Ducklow); a carbon equivalent of $20 \mathrm{fgC} \mathrm{cell}^{-1}$ was assumed (Lee \& Fuhrman 1987).

Several shipboard microcosm experiments were conducted to estimate flagellate growth and mortality. Plume surface water, collected in 301 Niskin bottles, was incubated for periods of 24 to $36 \mathrm{~h}$ in 3 acid-rinsed $20 \mathrm{l}$ polyethylene carboys. One carboy was an untreated control, one contained water screened through a fine Nitex mesh $(20 \mu \mathrm{m}$ in June, $10 \mu \mathrm{m}$ in April and August) to eliminate both macro- and microzooplankton-sized predators, and one contained water screened through a 64 um mesh to eliminate larger predators only. The carboys were maintained at in situ temperatures in a bath of running surface seawater, and sampled 3 to 6 times. Flagellates were enumerated as above. 


\section{RESULTS}

Heterotrophic microflagellate abundances were similar in all seasons, ranging from a few hundred to ca $10^{4}$ cells $\mathrm{ml}^{-1}$ (Fig. 2). Because bacterial abundance was substantially lower in February, flagellate biomass was much higher in relation to bacterial biomass then. In February, the ratio of flagellate carbon to bacterial carbon was 0.25 while in April, June and August it was $0.04,0.03$, and 0.06 , respectively. In winter, a higher fraction of the flagellate community was comprised of choanoflagellates $(22 \%$ of all flagellates in February, vs 10,4 , and $5 \%$ for April, June and August, respectively). The remainder of the assemblage was composed of chrysomonads, cryptomonads, bodonids, and other, unidentified flagellates.

Composite size spectra (all stations combined for one map in each cruise) are shown in Fig. 3. Flagellates were largest, on average, in winter, and decreased from $3.72 \mu \mathrm{m}$ average equivalent spherical diameter in February to $2.95 \mu \mathrm{m}$ in August, a decline of over $50 \%$ in cell volume. There was also a shift in modal diameter in August, with the very smallest cells dominating the community biovolume. Very small eukaryotic cells, less than $2 \mu \mathrm{m}$ in diameter and apparently lacking chloroplasts, were seen in all seasons. They were enumerated separately, but are not included in biovolume or abundance calculations discussed here because it was very difficult to distinguish whether these cells were truly aplastidic. Also, little or nothing is known about their ecology, in particular whether they are phagotrophic, in common with most cultured forms, or osmotrophs, capable of utilizing dissolved organic matter (Sherr 1988). The abundance of these cells at times equalled that of the larger flagellates, but because of their small size they rarely surpassed $10 \%$ of the total flagellate biovolume. Flagellates larger than $10 \mu \mathrm{m}$ were rare and may have been undersampled with our counting technique. Thus most of the forms included in

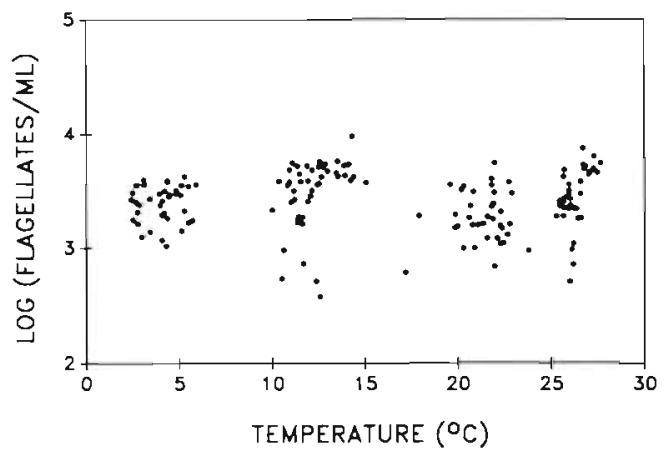

Fig. 2. Abundance of heterotrophic nanoflagellates versus temperature for all map data combined. The 4 clusters of points correspond to the 4 cruises, in February, April, June, and August, respectively, from left to right

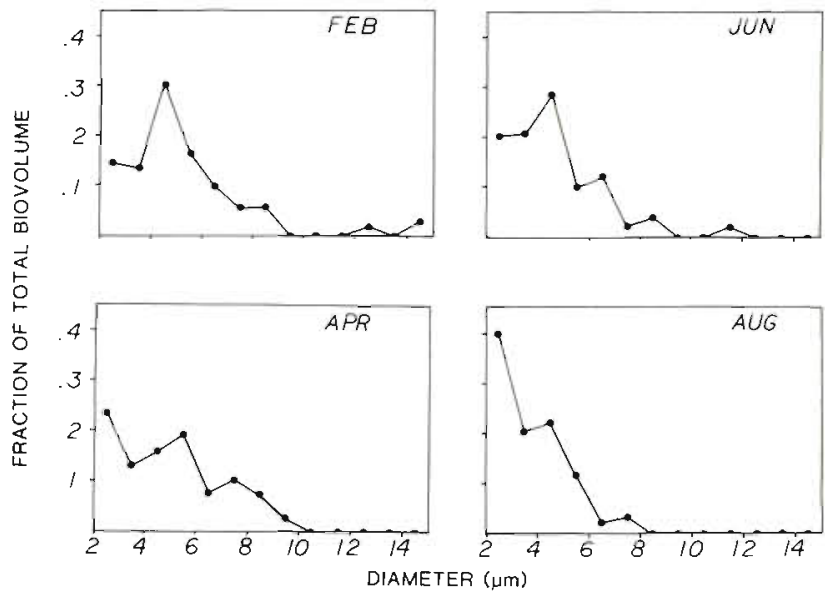

Fig. 3. Relative contributions of different size categories to the total flagellate community biovolume. Mean equivalent spherical diameters were $3.72,3.45,3.41$, and $2.95 \mu \mathrm{m}$ for February, April, June and August, respectively

the present study were 2 to $10 \mu \mathrm{m}$ in diameter and are considered here to be similar in ecology to the bacterivorous flagellates studied by Fenchel (1982a, b, 1986).

Representative maps of salinity and flagellate abundance are shown in Fig. 4. Flagellate abundance was negatively correlated with salinity within each cruise (except April) and for all cruises taken together (Table 1). The plume was thus a source of flagellates to the shelf.

Changes in abundance of flagellates with time were evaluated while following drogues deployed at the

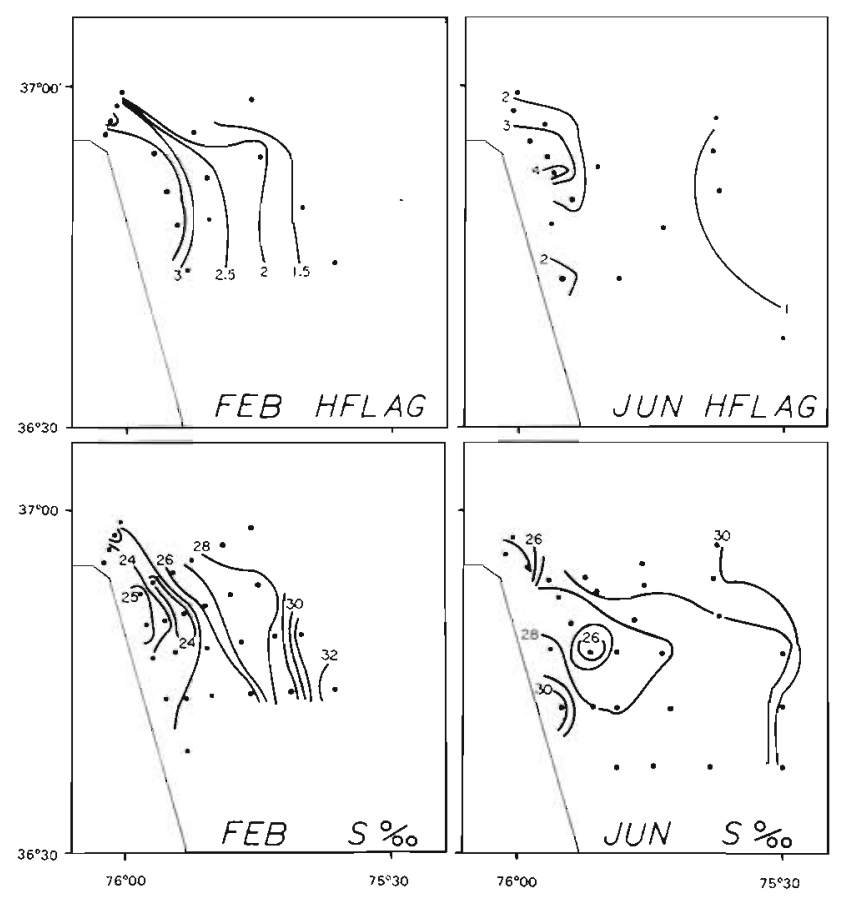

Fig. 4. Representative maps of salinity $\left(\mathrm{g} \mathrm{kg}^{-1}\right)$ and heterotrophic nanoflagellate abundance $\left(\times 10^{6}\right.$ cells $\left.1^{-1}\right)$ from the February and June cruises 
Table 1. Linear regressions of heterotrophic nanoflagellate abundance $(H N A B)$ versus salinity, for the map data

\begin{tabular}{lllr}
\hline Cruise & Regression & $r^{2}$ & $n$ \\
\hline Feb & HNAB $=8731-233.8$ Salinity & $0.442 \cdots$ & 39 \\
Apr & HNAB $=7374-135.2$ Salinity & $0.023 \mathrm{~ns}$ & 47 \\
Jun & HNAB $=11609-329.2$ Salinity & $0.387 \cdots$ & 42 \\
Aug & HNAB $=21022-626.6$ Salinity & $0.367 \cdots$ & 32 \\
All data & HNAB $=11370-300.5$ Salinity & $0.187 \cdots$ & 160 \\
$\cdots p<0.01$ & & \\
ns: not significant & & \\
\end{tabular}

mouth of the Bay (Fig. 5). In February, flagellate populations showed little change over the first $30 \mathrm{~h}$ in both drogue studies, but declined sharply on the second day of the second drogue. In April, flagellate populations showed no change with time during any of the 3 drogue deployments, while populations generally declined downstream in the plume during the June and August cruises.

Results from the carboy experiments are summarized in Table 2. Linear regressions fit the data of all experiments better than log-transformed regressions (except for the first April experiment: $r^{2}=0.87$ for linear, 0.89 for $\ln$-transformed), so the former were used to calculate growth rates. Population turnover times (slope of the increase in the smallest size fraction divided by initial abundance) ranged from undetectable to $1.6 \mathrm{~d}^{-1}$. In 2 out of 3 April experiments, growth was undetectable, and in the third a lag of about $14 \mathrm{~h}$ preceded growth. In June and August there were no lags before initiation of growth. Growth rates were about $1 \mathrm{~d}^{-1}$, with June growth being slightly higher than that in August. Where significant growth was measured, it
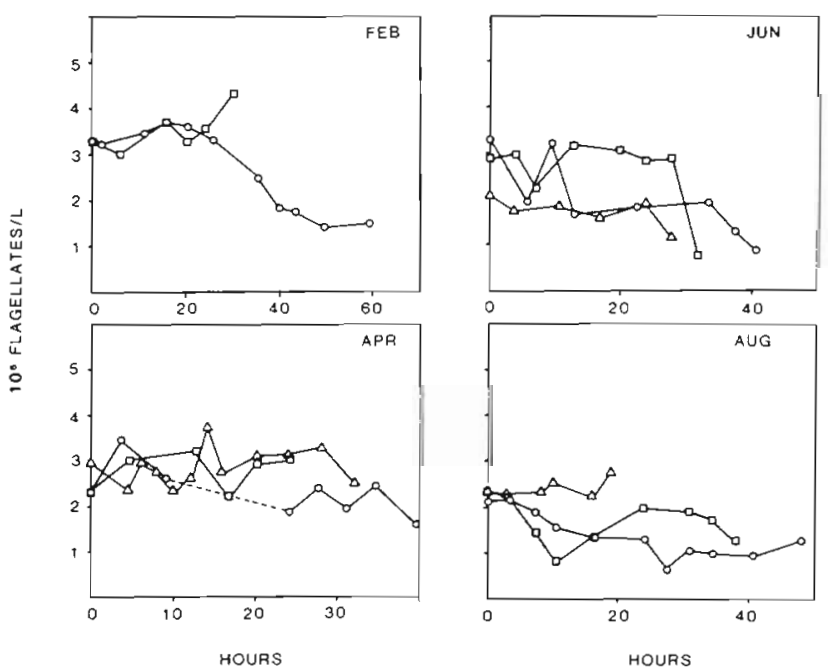

Fig. 5. Changes in flagellate abundance during drogue studies. Symbols represent different drogue tracks. Note different $x$-scales
Table 2. Flagellate growth rates in microcosms. Growth rates are slopes of linear regressions of flagellate abundance vs time, divided by initial measured abundance. Growth in the first April experiment ( $<10$ um treatment) was not significant for the first $24 \mathrm{~h}$

\begin{tabular}{|c|c|c|c|c|c|}
\hline \multirow[t]{2}{*}{ Cruise } & \multirow[t]{2}{*}{ Expt } & \multirow[t]{2}{*}{ Length $(\mathrm{h})$} & \multicolumn{3}{|c|}{ Growth rate $\left(\mathrm{d}^{-1}\right)$} \\
\hline & & & $<10 \mu \mathrm{m}^{\mathrm{d}}$ & $<64$ !m & Control \\
\hline \multirow[t]{3}{*}{ Apr } & 1 & 38 & 1.2 & ns & ns \\
\hline & 2 & 24 & ns & ns & ns \\
\hline & 3 & 36 & ns & ns & ns \\
\hline \multirow[t]{2}{*}{ Jun } & 1 & 24 & 1.2 & ns & ns \\
\hline & 2 & 24 & 1.6 & 0.6 & 1.0 \\
\hline \multirow[t]{2}{*}{ Aug } & 1 & 24 & 0.7 & ns & ns \\
\hline & 2 & 24 & 1.1 & ns & ns \\
\hline
\end{tabular}

was always greatest in the smallest size fraction (predator-free). Growth in the control and $<64 \mu \mathrm{m}$ carboys was significant only in the first June experiment. There was never any significant difference between the control and $<64 \mu \mathrm{m}$ treatments (test for equality of regression slopes, $p>0.05$; Sokal \& Rohlf 1969).

\section{DISCUSSION}

The lack of seasonal variability in flagellate abundance within the plume is striking. Ranges in abundance were very similar for all 4 cruises (Fig. 2). This is contrary to the idea, based on predator-prey dynamics, that variations in bacterial populations will be amplified in bacterivores (Fenchel 1986). For all 4 cruises, the variance in flagellate abundance was less than that of the bacteria, even though flagellate abundance was measured with lower precision (fewer organisms counted per slide). Low flagellate variability, even when growth rates were high (cf. June and August carboy experiments), implies the flagellates were themselves tightly controlled by grazers. These grazers most likely were ciliates, larger heterotrophic flagellates, and other microzooplankton. Ciliate abundances in the unscreened carboys averaged 6145 ind. $\mathrm{I}^{-1}$ (SE 1096; 28.4 um average equivalent spherical diameter) for the June and August experiments (no ciliate counts were made in April). At that level of abundance, a filtration rate of $6.8 \mu \mathrm{l}$ ciliate ${ }^{-1} \mathrm{~h}^{-1}$ would be required for the ciliates to clear the water of flagellates once per day. This is well within the range of published values for ciliate clearance rates (Heinbokel 1978, Capriulo 1982, Rassoulzadegan 1982, Verity 1985). Thus, ciliates had the potential to account for all of the flagellate grazing mortality. Removal of grazers larger than $64 \mu \mathrm{m}$ never resulted in significant increased growth of 
flagellates relative to unscreened controls. This suggests the chief grazers of flagellates were organisms smaller than $64 \mu \mathrm{m}$, and supports the idea that there are multiple trophic steps within the nano- and microplankton size fractions (Rassoulzadegan \& Sheldon 1986, Wikner \& Hagström 1988).

Flagellate biomass was higher, relative to that of bacteria, during winter. We reported earlier that flagellate grazing could account for most of the bacterial production in winter, but not in late spring (McManus \& Fuhrman 1988). Nanoflagellates are probably under greater grazing pressure in summer (discussed below), so other bacterivores, such as ciliates, may be more important then (Sherr \& Sherr 1987).

Bacterial and flagellate abundances were uncorrelated $(\mathrm{p}>0.05, \mathrm{n}=160$ ) for the whole map data set. This agrees with the results of Wright (1988), whose model of seasonal interactions between bacteria and flagellates in an estuary showed that when sampled across temporal or spatial scales at which both substrate and grazer control are exercised upon the bacteria, the 2 populations will generally not be correlated.

Fenchel (1986) argued that the ratio of bacteria to bacterivorous flagellates should be lower in eutrophic than in oligotrophic environments. In oligotrophic environments, low substrate supply keeps bacterial abundance at or below grazing thresholds. In eutrophic environments, increased substrate permits bacterial populations to grow up to a concentration at which flagellate grazing becomes more efficient. Some largescale observations on nanoflagellate abundance and distribution have been reported, and they generally agree with this rule. Going from an estuary to oligotrophic ocean waters, the order of decline in abundance is phytoplankton (as chlorophyll) $>$ heterotrophic nanoflagellates $>$ bacteria, and the ratio of bacteria to nanoflagellates increases with water depth (Sieburth \& Davis 1982, Davis et al. 1985). We examined our data relative to this prediction, using

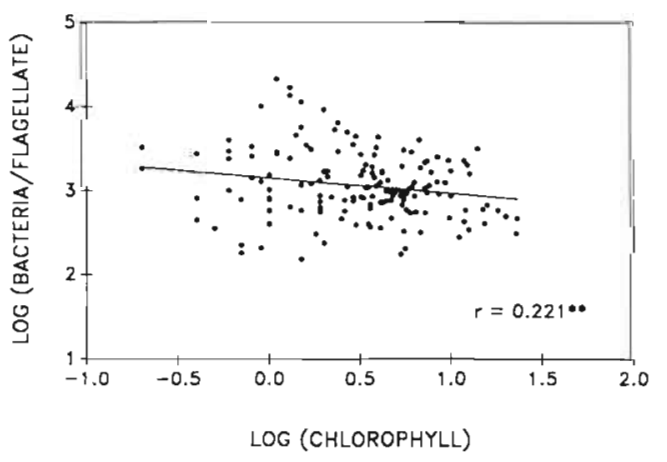

Fig. 6. Bacteria-to-flagellate ratio as a function of chlorophyll concentration $\left(\mu \mathrm{g}^{-1}\right)$, for all map data combined. Regression is significant $(p<0.01)$ chlorophyll as the measure of eutrophy, to see if the same pattern could be observed at the mesoscale (Fig. 6). Although there is much scatter in the data, the ratio of bacteria to flagellates declines significantly with chlorophyll for the combined map data $(p<0.01)$. This supports the idea that even at the smaller scales of such coastal features as estuarine plumes, both substrate supply and grazing can regulate bacterial populations.

If flagellate growth, death, and loss from the plume due to mixing are considered first order exponential processes, then

$$
\mathrm{dN} / \mathrm{dt}=\mathrm{N}(\mathrm{r}-\mathrm{g}-\mathrm{k}),
$$

where $\mathrm{N}=$ flagellate abundance at time $\mathrm{t}$ within the plume; coefficients $r, g$, and $\mathrm{k}=$ first order rate constants for growth, mortality, and mixing losses, respectively, with dimension of $\mathrm{t}^{-1}$. The net change, $\mathrm{dN} / \mathrm{dt}$, is equal to the observed in situ change in flagellate abundance with time during the drogue studies. In our carboy experiments, the change in flagellate abundance in the control (untreated) carboys equals ( $r-g$ ), the net result of growth and grazing in the absence of mixing losses. Thus $\mathrm{k}$, the loss constant due to mixing, can be estimated by subtracting in situ changes in plume flagellate populations from observed changes in the control carboys,

$$
\mathrm{k}=(\mathrm{r}-\mathrm{g})-1 / \mathrm{N} \mathrm{dN} / \mathrm{dt} .
$$

We plotted $\ln \left(N_{t} / N_{0}\right)$ versus elapsed time for the drogue data, all drogues combined within a given cruise, for April, June, and August. Least squares regressions indicated no significant net change during April, and losses of $0.35 \mathrm{~d}^{-1}$ in both June and August. June and August regressions were significant $(p<0.01)$. These slopes represent the quantity $1 / \mathrm{N}$ $\mathrm{dN} / \mathrm{dt}$ in the equation above, and can be used to obtain an estimate of the time scale for flagellate populations to be mixed out of the plume.

In 6 of the 7 carboy experiments, untreated controls showed no significant change in flagellate abundance over 24 to $38 \mathrm{~h}$. This supports the idea that growth and mortality were usually balanced within the plume ([r g] $=0$ in Eq. 2). Thus net changes were due to mixing losses. In April, net in situ changes, growth and mortality were all undetectable (except for the one carboy experiment, wherein significant growth followed a $14 \mathrm{~h}$ lag). Thus population dynamics were minimal during April. In June and August growth and mortality were substantially higher than losses due to mixing (growth rates of 0.7 to $1.6 \mathrm{~d}^{-1}$, versus mixing losses of $0.35 \mathrm{~d}^{-1}$ ).

This approach provides only an approximation. For example, although exponential growth is assumed in Eq. (1), a linear model provided the best empirical fit to the carboy data. Also, exponential mixing loss is not an appropriate assumption for the April data because 
flagellate abundance was not significantly lower outside the plume (Table 1). In fact, physical mixing dominated the distributions of other biological properties in April, when strong northerly winds $\left(10\right.$ to $\left.30 \mathrm{~m} \mathrm{~s}^{-1}\right)$ rapidly mixed the plume with surrounding coastal waters (Malone \& Ducklow in press). Thus, although mixing was strong in April, flagellate abundance in the plume changed little because abundance was similar in the coastal water. The conclusion that the time scale for mixing is several-fold longer than generation time remains valid for June and August, when both freshwater discharge and wind speed were lower, and flagellate populations were higher within the plume. The carboy experiments thus confirm that flagellate growth and mortality are closely coupled within the plume, and that observed net population changes in situ were controlled by physical processes.

Although physical and biological variability associated with estuarine plumes is great, they are useful model systems for studying interactions among microbial populations. Their spatial extent and persistence allow them to be mapped quasi-synoptically by a single ship in 1 to $2 \mathrm{~d}$. Physical processes determining the rate at which a plume mixes with shelf water occur on a time scale commensurate with microbial generation times. Using a combination of observation and experimentation, physical controls on microbial populations can be separated from biological ones. In the present study, these indicated that heterotrophic nanoflagellates and their predators are closely coupled within the plume and that mixing with shelf water drives net population change.

Acknowledgements. We thank Drs W. Boicourt, H. Ducklow, C. Garside, P. Glibert, T Malone, M. Roman, L. Sanford, and the other MECCAS scientists for sharing ideas and data. A. Gauzens, S. Hill, and K. Ashton helped with the carboy experiments. J. McDaniel and A. Chan performed a large share of the microscopy. The comments of H. Carrick and E. Lessard on the manuscript are appreciated. This research was supported by grant OCE 8545037 from the National Science Foundation (USA).

\section{LITERATURE CITED}

Albright, L. J. (1983). Influence of river-ocean plumes upon bacterioplankton production of the Straight of Georgia, British Columbia. Mar. Ecol. Prog. Ser. 12: 107-113

Boicourt, W. C., and co-authors (1987). Physics and microbial ecology of a buoyant estuarine plume on the continental shelf. EOS Trans. Am. geophys. Ln. 68: 666

Bloem, J., Bar-Gilissen, M. B., Cappenberg, T E. (1986). Fixation, counting and manipulation of heterotrophic nanoflagellates. Appl. envirl Microbiol. 52: 126(j-1272

Børsheim, K. Y., Bratbak, G. (1987). Cell volume to cell carbon conversion factors for a bacterivorous Monas sp. enriched from seawater. Mar. Ecol. Prog. Ser. 36: 171-175

Capriulo, G. M. (1982). Feeding of field collected tintinnid microzooplankton on natural food. Mar. Biol. 71: 73-86
Davis, P. G., Caron, D. A., Johnson, P. W., Sieburth, J. McN. (1985). Phototrophic and apochlorotic components of picoplankton and nanoplankton in the North Atlantic: geographic, vertical, seasonal and diel distributions. Mar. Ecol. Prog. Ser 21: 15-26

Ducklow, H. W., Kirchman, D. L. (1983). Bacterial dynamics and distribution during a spring diatom bloom in the Hudson River plume, USA. J. Plankton Res. 5: 333-355

Fenchel, T. (1982a). Ecology of heterotrophic microflagellates. I. Some important forms and their functional morphology. Mar Ecol. Prog. Ser. 8: 211-223

Fenchel, T. (1982b). Ecology of heterotrophic microflagellates. II. Bioenergetics and growth. Mar Ecol. Prog. Ser 8 225-231

Fenchel, T (1986). The ecology of heterotrophic flagellates. Adv. microb. Ecol. 9: 57-97

Garvine, R. W (1986). The role of brackish plumes in open shelf waters. In: Skreslet, S (ed.) The role of freshwater outflow in coastal marine ecosystems. Springer-Verlag, Berlin, p. 47-65

Goldman, J. C. (1984). Oceanic nutrient cycles. In: Fasham, M. J. (ed.) Flows of energy and materials in marine ecosystems. Plenum, New York, p. 137-170

Goldman, J. C., Caron, D. A. (1985). Experimental studies on an omnivorous microflagellate: implications for grazing and nutrient regeneration in the marine microbial food chain. Deep Sea Res. 32: 899-915

Goldman, J. C., Caron, D. A., Ketil-Andersen, O., Dennett, M. R. (1985). Nutrient cycling in a microflagellate food chain. I. Nitrogen dynamics. Mar Ecol. Prog. Ser 24: $231-242$

Haas, L. W. (1982). Improved epifluorescence microscopy for observing planktonic micro-organisms. Annls Inst. océanogr., Paris 58(S): 261-266

Haas, L. W., Webb, K. L. (1979). Nutritional mode of several non-pigmented microflagellates from the York River estuary, Virginia. J. exp. mar. Biol. Ecol. 39: 125-134

Heinbokel, J. F. (1978). Studies on the functional role of tintinnids in the Southern California Bight. I. Grazing and growth rates in laboratory cultures. Mar Biol. 47. 177-189

Hobbie, J. E., Daley, R. J., Jasper, S. (1977). Use of Nuclepore filters for counting bacteria by fluorescence microscopy. Appl. envirl Microbiol. 33: 1225-1228

Iturriaga, R., Mitchell, B. G. (1986). Chroococcoid cyanobacteria: significant component in the food web dynamics of the open ocean. Mar Ecol. Prog. Ser. 28: 281-297

Johnson, P. W., Huai-shu, X., Sieburth, J. McN. (1982). The utilization of chroococcoid cyanobacteria by marine protozooplankters but not by calanoid copepods. Annls Inst. océanogr., Paris 58(S): 297-308

Kirchman, D., Soto, Y., van Wambeck, F., Bianchi, M. (1989). Bacterial production in the Rhone River plume: effect of mixing on relationships among microbial assemblages. Mar. Ecol. Prog. Ser. 53: 267-275

Landry, M. R. Haas, L. W., Fagerness, V L. (1984). Dynamics of microbial plankton communities: experiments in Kaneohe Bay, Hawaij. Mar Ecol. Prog. Ser. 16: 127-133

Lee, S., Fuhrman, J. A. (1987). Relationship between biovolume and biomass of naturally-derived marine: bacterioplankton. Appl. envirl Microbiol. 53: 1298-1303

Malone, T. C., Chervin, M. B. (1979). The production and fate of phytoplankton size fractions in the plume of the Hudson. River, NY Bight. Limnol. Oceanogr. 24: 683-696

Malone, T. C., Ducklow, H. W. (in press). Microbial biomass in the coastal plume of the Chesapeake Bay: phytoplanktonbacterioplankton relationships. Limnol. Oceanogr

Malone, T C., Hopkins. T. S, Falkowski, P. G., Whitledge, T 
E. (1983). Production and transport of phytoplankton biomass over the continental shelf of the New York Bight. Cont. Shelf Res. 1 305-337

McManus, G. B., Fuhrman, J. A. (1988). Clearance of bacteriasized particles by natural populations of nanoplankton in the Chesapeake Bay outflow plume. Mar. Ecol. Prog. Ser 42: $199-206$

Rassoulzadegan, F. (1982). Dependence of grazing rate, gross growth efficiency and food size on temperature in a pelagic oligotrichous ciliate Lohmaniella spiralis LEEG., fed on naturally occurring particulate matter Annls Inst. océanogr., Paris 58(S): 177-184

Rassoulzadegan, F., Sheldon, R. W. (1986). Predator-prey interactions of nanozooplankton and bacteria in an oligotrophic marine environment. Limnol. Oceanogr 31: 1010-1021

Sherr, B. F., Sherr, E. B., Berman, T. (1983). Grazing, growth, and ammonium excretion rates of a heterotrophic microflagellate fed with four species of bacteria. Appl. envirl Microbiol. 45: 1196-1201

Sherr, E. B. (1988). Direct use of high molecular weight polysaccharide by heterotrophic flagellates. Nature, Lond. 335 : 348-351

This article was presented by Drs E. \& B. Sherr, Sapelo Island, Georgia, USA
Sherr, E. B., Sherr, B. F. (1987). High rates of consumption of bacteria by pelagic ciliates. Nature, Lond. 325: 710-711

Sieburth, J. M., Davis, P. G. (1982). The role of heterotrophic nanoplankton in the grazing and nurturing of planktonic bacteria in the Sargasso and Caribbean Seas. Annls Inst. océanogr., Paris 58(S): 285-296

Sokal, R. R., Rohlf, F. J. (1969). Biometry. W. H. Freeman, San Francisco

Stepien, J. C., Malone, T C., Chervin, M. B. (1981). Copepod communities in the estuary and coastal plume of the Hudson River Est. cstl Shelf Sci. 13: 185-195

Suttle, C. A., Chan, A. M., Taylor, W. D., Harrison, P. J. (1986). Grazing of planktonic diatoms by microflagellates. J. Plankton Res. 8: 393-398

Verity, P. G. (1985). Grazing, respiration, excretion, and growth rates of tintinnids. Limnol. Oceanogr 30: 1268-1282

Wikner, J., Hagström, $\AA$. (1988). Evidence for a tightly coupled nanoplanktonic predator-prey link regulating the bacterivores in the marine environment. Mar. Ecol. Prog. Ser. 50: $137-145$

Wright, R. T. (1988). A model for short-term control of the bacterioplankton by substrate and grazing. Hydrobiologia 159: $111-117$

Manuscript first received: August 28, 1989

Revised version accepted: December 22, 1989 